\title{
Effects of winter temperature on phytoplankton development in acidic mining lakes
}

\author{
Dieter Lessmann, Hilmar Hofmann, Camilla Beulker and Brigitte Nixdorf
}

\section{Introduction}

Mining lakes are within the focus of limnological and public interest in many countries because they have unusal mineral content and can comprise a great portion of standing waters in certain areas. Due to pyrite oxidation, many mining lakes are extremely acidic and therefore differ considerably from natural circumneutral lakes in their chemical and biological characteristics (GELler et al. 1998, LESSMANN \& NIXDORF 2000).

In central Europe deep lakes are usually regarded as dimictic. A presupposition for stable winter stagnation is the formation of ice cover, which depends on the duration of the frost period. Within the last ten years central Europe has seen several mild winters that inhibited the formation of a long-lasting ice cover and thus the occurrence of a stable winter stagnation.

The importance of occurrence and duration of winter ice cover and winter stagnation for the phytoplankton development is shown by the example of Mining Lake (ML) Plessa 117 of the Lusatian lignite mining district (Germany). This study compares the relatively mild winter 2001/2003 with the strong winter 2002/2003 and analyzes phytoplankton development in winters of 1997 to 2000 .

Key words: phytoplankton, winter stagnation, acidic mining lake, inorganic carbon, total phosphorus

\section{Study site}

Since the end of the $19^{\text {th }}$ century, the Lusatian region around Cottbus has been one of the most important opencast lignite mining areas in Germany. Mining Lake Plessa 117 (Brandenburg, Germany) is about 35 years old. With an area of $0.95 \times 10^{6} \mathrm{~m}^{2}$, a volume of $5.7 \times 10^{6} \mathrm{~m}^{3}$ and a maximum and mean depth of $14.4 \mathrm{~m}$ and $6 \mathrm{~m}$, the lake belongs to the medium-sized mining lakes of the Lusatian mining district. The lake is mainly fed by groundwater inflow (73\% of total inflow; HOFMANN \& LESSMANN 2006). Its main chemical features are a $\mathrm{pH}$ around 3 with a moderate acidity (Ks4.3:-1.8 mmol/1), and sulphate, calcium and iron as the most important ions (mean conductivity: $1000 \mu \mathrm{S} / \mathrm{cm}$ ). According to mean phosphorus and chlorophyll- $a$ concentrations, the lake can be classified as oligotrophic.

\section{Materials and methods}

Since 1995, Lake Plessa 117 has been investigated within a monitoring programme using a standard sampling frequency of 2-8 weeks. Programme measurements included depth profiles of water temperature, oxygen concentrations, $\mathrm{pH}$ and conductivity with a multi-parameter probe (HYDROLAB H20). A fluorescence probe (HAARDT Backscat) was used for measuring depth profiles of chlorophyll- $a$ concentrations. Samples for chemical and biological analyses were taken at the deepest point of the lake with a LIMNOS 2.01 water sampler from mixed $0.5 \mathrm{~m}$ depth interval samples (surface-to-bottom vertical "profile" sampling during circulation periods and separate vertical epilimnion and hypolimnion sampling during summer stagnation phases). Samples for total inorganic carbon (TIC) analyses were restricted to the middle of each layer to prevent air contact. TIC concentrations were measured by infrared spectrometry (DIMATEC Dima-TOC 100), and phosphate concentrations were determined spectrophotometrically (Perkin-Elmer Lambda) by standard German methods (DEV 1981-2003). Phytoplankton samples were fixed by Lugol's solution. For determination, counting and measurement the Utermöhl method was used (UTERMÖHL 1958).

\section{Results and discussion}

Ice cover and temperature stratification During the mild winter 2001/2002, 10-day mean temperatures stayed in the negative range only from the middle of December to the middle of January and afterward were only occasionally below $0{ }^{\circ} \mathrm{C}$. In contrast, during winter $2002 / 2003$, temperatures were nearly continu- 
ously in the negative range from the middle of December to the end of February. Night frost regularly occurred until April. As a consequence, during winter 2001/2002, the lake was covered by a thin ice layer only in January for about two weeks, while during the strong winter 2002/2003 a long-lasting ice cover occurred from the beginning of December until the end of March. The ice reached a thickness of up to $25 \mathrm{~cm}$.

Due to the long-lasting ice cover during winter 2002/2003, inverse temperature stratification was observed, which was stabilized by the inflow of groundwater into the deepest parts of the lake. In contrast, during winter 2001/2002 no temperature stratification occurred.

\section{Nutrient concentrations \\ Total phosphorus concentrations with a mean value of $8 \mu \mathrm{g} / 1(1996-2003)$ and $10 \mu \mathrm{g} / \mathrm{l}$ (2001-2003) were relatively stable during the years of investigation. Values up to $18 \mu \mathrm{g} / 1$ in the hypolimnion during summer stagnation showed that the deepest parts of the lake had clearly higher phosphorus concentrations than the rest of the lake. Phosphorus concentrations in the surrounding groundwater reached $100-240 \mu \mathrm{g} / 1$ and seepage concentrations ex- ceeded the concentrations in the lake several times (HOFMANN \& LESSMANN 2006). Dis- solved inorganic phosphorus (DIP) concentra- tions remained low, only $3 \mu \mathrm{g} / \mathrm{l}$, during both winters. This low phosphorus level supports the argument for efficient uptake of phosphorus by organisms.}

Another crucial variable for primary production was the concentration of inorganic carbon. During winter 2002/2003, measurement from the middle of the water column showed concentrations mainly $=1 \mathrm{mg} / 1$, interrupted by a shortterm decrease to $0.5-0.6 \mathrm{mg} / 1$, which may be due to intensive algae uptake.

Low $\mathrm{pH}$ and absence of the carbonate buffering system limited inorganic carbon occurrence to carbon dioxide, which strived to reach equilibrium with the low atmosphere concentrations. Therefore, high inorganic carbon concentrations could only be found in the hypolimnion of summer stagnation and during winter under ice cover. The main sources of inorganic carbon were the carbon-dioxide-rich groundwater and decomposition processes.

Therefore, in acidic mining lakes the seasonal succession of phytoplankton is first determined by availability of inorganic carbon (TIC) and by phosphorus concentrations (LESSMANN \& NiXDORF 2002, BEULKER et al. 2003). Grazing zooplankton are able to influence phytoplankton development only for some time during summer (DENEKE et al. 2002, BEULKER et al. 2004).

\section{Chlorophyll-a concentrations}

The temporal development of the mean chlorophyll- $a$ concentrations in the water column showed a steady increase in winter 2002/2003 during the time of ice cover from $1 \mu \mathrm{g} / 1$ to nearly $10 \mu \mathrm{g} / \mathrm{l}$. During this strong winter the increase in chlorophyll- $a$ concentrations was stronger and more continuous than during the mild winter 2001/2002 (Figs. 1 and 2). Measurements with the fluorescence probe clearly showed that deep chlorophyll maxima were typical for both winters. During winter 2001/2002, chlorophyll$a$ concentrations seemed to indicate the mixing depth of the water column.

Occurrence of the short-lasting ice cover in January 2002 enabled the phytoplankton to also colonize the upper water body. Nevertheless, the highest chlorophyll- $a$ concentrations occurred in the nutrient-rich zones close to the lake bottom. During winter 2002/2003, a rapid increase in chlorophyll-a concentrations was observed immediately after the formation of an ice cover in December 2002. One month later, after a short time decrease, the concentrations reached their highest values close to the bottom, as in the mild winter before.

The distribution of chlorophyll- $a$ concentrations of both winters clearly illustrated the high importance of the nutrient supply of the phytoplankton by groundwater sources, which mainly flow into the deepest parts of the lake. The longer the period of temperature stratification associated with the stratification of TIC and phosphorus, the higher the algae growth.

\section{Winter periods $1997-2000$}

Three relatively mild winters, 1997-2000, showed different durations of ice cover. While 

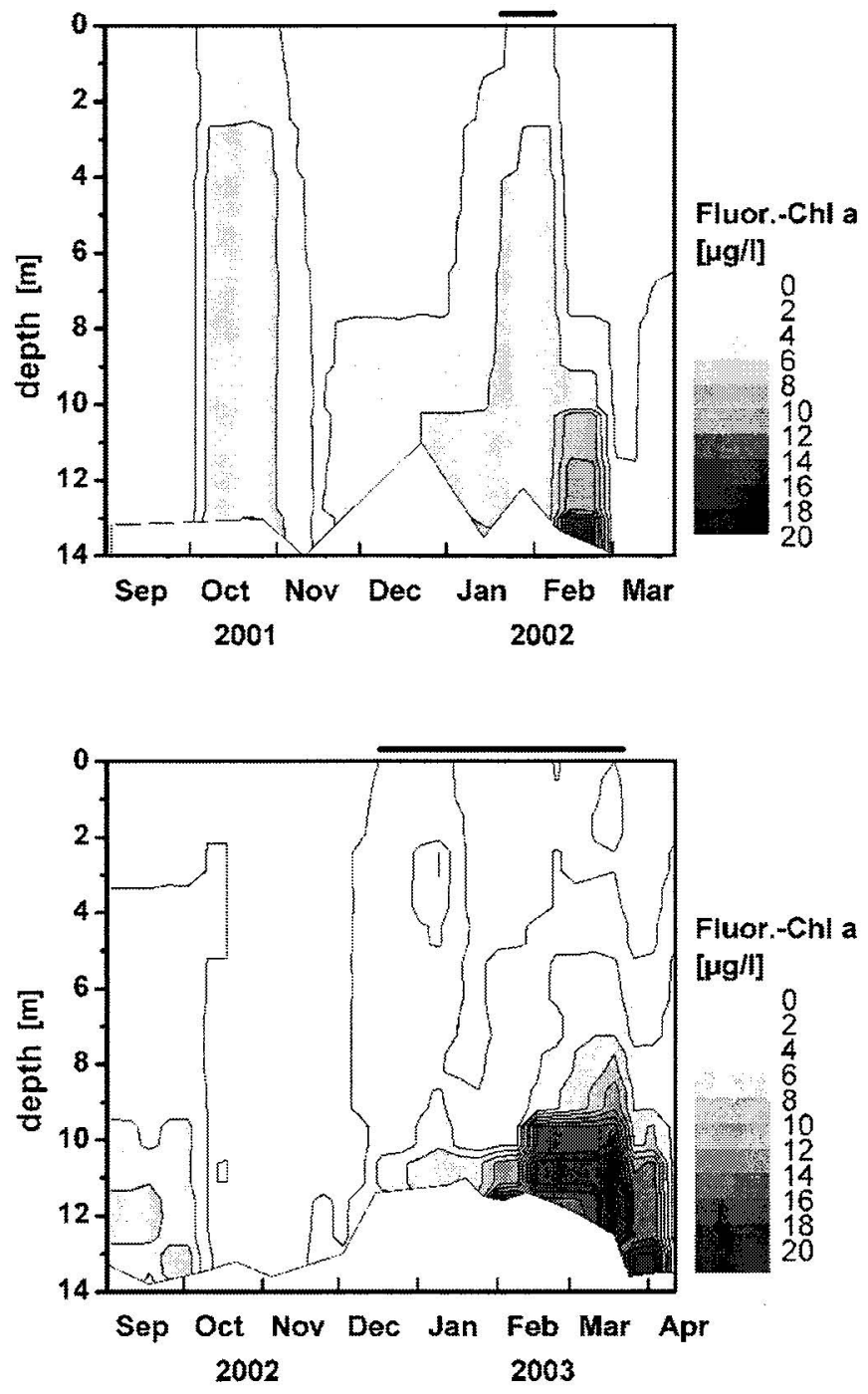

Fig. 1. Fluorescence chlorophyll- $a$ concentrations during the mild winter 2001/2002 (times of ice cover indicated by bars).
Fig. 2. Fluorescence chlorophyll- $a$ concentrations during the strong winter 2002/2003 (times of ice cover indicated by bars). winters $1997 / 1998$ and $1999 / 2000$ led to ice cover that lasted about two weeks, winter 1998/1999 had a thin ice cover only twice, which lasted for only a few days. The consequences to phytoplankton development were obvious. The formation of a stable winter stagnation enabled a fast increase in phytoplankton growth, which in contrast to winter 2002/2003 was not preferably limited to the zones close to the bottom of the lake. Winter 1998/1999 also showed an increase in chlorophyll- $a$ concentrations at a depth between 6 and $13 \mathrm{~m}$, and was lower than during the other winters.

\section{Winter algae communities}

In all years, the winter algae communities mainly consisted of three taxa: Chlamydomonas (Chlorophyceae), Ochromonas (Chrysophyceae) and Gymnodinium (Dinophyceae). With regard to biovolume, blooms in winters with a stable stagnation could mainly be attributed to Ochromonas (1997/1998 and 1999/2000) or to Gymnodinium (2001/2002), and in the winter with the extremely short lasting stagnations mainly to Gymnodinium (1998/1999; Table 1). Chlamydomonas biovolumes during winter only once exceeded 0.15 
Table 1. Maximum taxa biovolume in $\mathrm{mm}^{3} / 1$ between December and March.

\begin{tabular}{lccc}
\hline Winter period & Chlamydomonas sp. & Ochromonas sp. & Gymnodinium sp. \\
\hline $1997 / 1998$ & 0.14 & 2.89 & 0.10 \\
$1998 / 1999$ & 0.12 & 0.12 & 0.43 \\
$1999 / 2000$ & 0.70 & 1.54 & 0.24 \\
$2001 / 2002$ & 0.02 & 0.08 & 0.37 \\
\hline
\end{tabular}

$\mathrm{mm}^{3} / 1$ and were much lower in most samples. For the winter 2002/2003 no data of phytoplankton composition were available.

Experiments have shown that primary production limitation in ML Plessa 117 is due to phosphorus as well as TIC concentrations with a threshold of $0.6 \mathrm{mg} / \mathrm{l}$ for TIC and $10 \mu \mathrm{g} / 1$ for TP (BEULKER et al. 2002). The phytoplankton development as it was observed in the lake seemed to be mainly controlled by these two nutrients; however, both Ochromonas and Gymnodinium are photoautotrophic and bacteriovorous.

\section{Conclusions}

Due to the increasing number of mild winters in central Europe with a sequence of short frost periods, the formation of long-lasting ice covers, which are a presupposition for stable winter stagnation, is decreasing.

- During winter, the phytoplankton development in acidic mining lakes is determined by the occurrence of a winter stagnation and its duration.

- Main source of nutrients for phytoplankton growth is the groundwater inflow. A stable stagnation phase leads to gradients in nutrient and chlorophylla concentrations in the water column. The ice cover prevents loss of inorganic carbon to the atmosphere.

- Only the formation of a winter stagnation lasting for longer than about one week enables the occurrence of algae blooms.

- The phytoplankton of the winter algae blooms is dominated by Ochromonas sp. (Chrysophyceae) or Gymnodinium sp. (Dinophyceae).

\section{Acknowledgements}

The authors thank REMO ENDER, JÖRG KOEBCKE and SIMONE PETERSOHN for assistance in sampling and chemical analyses. The study was financially supported by the German Research Foundation (DFG) (SFB 565).

\section{References}

Beulker, C., Krumbeck, H., Nixdorf, B. \& Jander, J., 2002: Primärproduktion in sauren Gewässern unter dem Einfluss der Ressourcenlimitation. - BTU Cottbus, Aktuelle Reihe 3/2002: 107-112.

Beulker, C., Lessmann, D. \& Nixdorf, B., 2003: Aspects of phytoplankton succession and spatial distribution in an acidic mining lake (Plessa 117, Germany). - Acta Oecol. 24: S25-S31.

Beulker, C., Deneke, R., Nixdorf, B., Wollmann, K., LessmanN, D., KamJunke, N. \& Rǘcker, J., 2004: Trophische Interaktionen in einem sauren Tagebausee (Plessa 117). - Dt. Ges. f. Limnol., Tagungsbericht (Köln) 2003, Bd. II: 737-742.

DENEKE, R., STÖBEL, K. \& NIXDORF, B., 2002: Welche Rolle spielt das Grazing des Metazooplankton für die Phytoplanktonentwicklung in sauren Tagebauseen (pH 2-4)? - Dt. Ges. f. Limnol., Tagungsbericht (Kiel), 2001: 401-405.

DEV, 1981-2003: Deutsche Einheitsverfahren zur Wasser-, Abwasser- und Schlammuntersuchung. VCH Verlagsges., Weinheim.

Geller, W., KlapPer, H. \& SAlomons, W. (Eds.), 1998: Acidic Mining Lakes. - Springer-Verlag, Berlin, 450 pp.

Hofmann, H. \& Lessmann, D., 2006: Hydrogeochemistry of groundwater seepage into an acidic mining lake. - Verh. Internat. Verein. Limnol. 29: 1452-1456.

LESSMANN, D. \& NiXdoRF, B., 2000: Acidification control of phytoplankton diversity, spatial distribution and trophy in mining lakes. - Verh. Internat. Verein. Limnol. 27: 2208-2211.

LeSSMANN, D. \& NiXdORF, B., 2002: Seasonal succession of phytoplankton in acidic mining lakes. - Verh. Internat. Verein. Limnol. 28: 1597-1601.

UTERMÖHL, H., 1958: Zur Vervollkommnung der quantitativen Phytoplankton-Methodik. - Mitt. Internat. Verein. Limnol. 9: 1-38.

Authors' address:

D. Lessmann, H. HofMAnN, C. Beulker, B. Nixdorf, Department of Freshwater Conservation, Brandenburg University of Technology, P.O. Box 101344, 03013 Cottbus, Germany;

E-mail: lessmann@tu-cottbus.de. 